\title{
The geographical context of wastewater treatment and reuse: a benchmarking analysis for Spanish \\ Mediterranean Wastewater Treatment Plants
}

El contexto geográfico del tratamiento y reutilización de aguas residuales:

un análisis benchmarking para el litoral mediterráneo español

\author{
Paula Rodríguez \\ paula_r_v@hotmail.com \\ Department of Geography \\ Universitat Autònoma de Barcelona (Spain) \\ David Palma \\ dpalma@besos-tordera.cat \\ LEQUIA, Institute of the Environment, Universitat de Girona (Spain)
}

CCB Serveis Mediambientals, SAU_Consorci Besòs Tordera, Granollers (Spain)

\author{
Manel Poch \\ manuel.poch@udg.edu \\ LEQUIA, Institute of the Environment \\ Universitat de Girona (Spain)
}

\section{Miquel À. Cugueró-Escofet}

macuguero@besos-tordera.cat

CCB Serveis Mediambientals, SAU-Consorci Besòs Tordera, Granollers (Spain) 


\author{
David Sauri \\ david.sauri@uab.cat \\ Department of Geography \\ Universitat Autònoma de Barcelona (Spain)
}

\begin{abstract}
This paper examines wastewater treatment and reuse in Catalonia and Valencia through a benchmarking analysis of energy intensities of wastewater treatment plants (WWTPs) located in the coastal municipalities of both regions also involving comparison with average European data on energy use by these plants. The comparison of European and Spanish Mediterranean WWTPs indicates that small Mediterranean plants are less energy intensive than their European counterparts, while for larger plants (above 10,000 $\mathrm{m}^{3}$ /day) the reverse is true. As to the comparison between Catalan and Valencian plants, the latter are generally smaller than the former, and also slightly more energy intensive. Regarding reuse, the geographical context would explain these differences in terms of the final destination of effluents treated in these plants. The important presence of irrigated agriculture in Valencia is responsible for the reuse of $45 \%$ of potentially reclaimed water while Catalonia, with a different socioterritorial reality, reuses less than $3 \%$ of the total effluent treated.
\end{abstract}

Key words: wastewater treatment; wastewater reuse; benchmarking; Catalonia; Valencia.

\title{
Resumen
}

Este artículo examina los tratamientos y la reutilización de las aguas residuales en Cataluña y Valencia a través de un análisis comparativo (benchmarking) de las intensidades energéticas de todas las plantas de tratamiento de aguas residuales (EDAR) ubicadas en los municipios costeros de ambas regiones, que también se comparan con los promedios europeos. La comparación de las EDAR mediterráneas europeas y españolas indica que la plantas mediterráneas más pequeñas son más eficientes energéticamente que sus equivalentes europeas, mientras que para las plantas grandes (más de $10000 \mathrm{~m}^{3} /$ día) se da el caso contrario. En cuanto a la comparación entre plantas catalanas y valencianas, estas últimas son generalmente más pequeñas que las primeras y un poco menos eficientes energéticamente. El contexto geográfico puede explicar estas diferencias en términos del destino final de los efluentes tratados en estas plantas. La gran presencia de la agricultura de regadío en Valencia es responsable de la reutilización del $45 \%$ de las aguas residuales tratadas, mientras que Cataluña, al carecer de esta alternativa, reutiliza menos del 3 \%, aunque se están explorando iniciativas de reutilización indirecta para usos potables.

Palabras clave: aguas residuales; reutilización; benchmarking; Cataluña; Valencia. 


\section{Introduction}

Water reuse is rapidly becoming a relevant alternative for water supply portfolios around the world (Sauri \& Arahuetes, 2019; Stijn et al., 2015; WWAP, 2017). Although still somewhat problematic in terms of public acceptance, the impressive technological advances of the last decades have turned these previously unwanted flows into critical resources, especially in areas threatened by recurrent episodes of water scarcity (Browning-Aiken et al., 2011; Duong and Spahores, 2015). In particular, the Mediterranean basin has undergone important social and environmental changes during the last decades that challenge current water supply systems (Choukr-Allah et al., 2012). The contrast between population, agricultural, and tourist growth and scarce and irregular precipitation patterns exacerbated by climate change produces scenarios of uncertain water availability. In addition, human activities have made the Mediterranean a sensitive environment to pollution, given the large amounts of untreated wastewater discharged to the sea (Cramer et al., 2018; Malagò \& Bouraoui, 2018). Therefore, water efficiency and alternative water resources such as desalination or treated wastewater represent fundamental strategies for many Mediterranean countries to respond to these challenges regarding both water quantity and quality (Iglesias et al., 2007).

This paper focuses on treated wastewater as a potentially important resource for future water supply portfolios of Mediterranean areas. More specifically, it examines the tradeoffs between water and energy to obtain effluents able to satisfy the water needs of these areas, at least for certain uses. In this sense, the paper falls within the scope of the so called "Water-Energy Nexus" (WEN) literature which assesses the relationships between these two resource flows (Solomon \& Calvert, 2017). WEN studies are interested in both, the water requirements for energy production (or, in standard terms, number of $\mathrm{m}^{3}$ of water needed for the production of $1 \mathrm{kWh}$ of energy) and the energy requirements for the mobilization of water in specific quantities and qualities for specific geographical areas and temporal frames; that is, the $\mathrm{kWh}$ needed for the production of $1 \mathrm{~m} 3$ of treated water (Yoon, 2019). The paper emphasizes the second aspect of WEN; that is, the energy needed (or energy intensity) for producing treated water flows with quality requirements addressed to different target uses. Despite their important social, territorial and environmental dimensions WEN studies in the area of wastewater treatment and reuse are relatively little explored in Geography (Sauri \& Arahuetes, 2019). In Spain, geographical perspectives on wastewater treatment and reuse have been developed for a number of years (Rico Amorós et al., 1998; Olcina \& Moltó, 2010) buy detailed studies on this topic are relatively rare.

The paper has two main objectives: First, using benchmarking methodology (see below), it attempts to compare the energy intensity of Mediterranean WWTPs in the Spanish coastal areas of Catalonia and Valencia (Figure 1) with European average values of the same variable. Energy intensity provides insight of the type and comprehensiveness of the treatment processes, although this needs 
to be complemented by economies of size, technological optimization and the possibility of energy generation by sludge. The second objective is to test whether energy intensities in Mediterranean WWTPs vary according to the final destination of the water treated. Hence, a comparison of Catalan and Valencian WWTPs is also made in terms of energy intensity for water reuse. In addition, tertiary treatments and water reuse strategies between the two Euro-Mediterranean regions will be discussed, focusing on energy efficiency, types of tertiary treatments and uses for treated water. A general feature of Mediterranean areas, in contrast with the rest of Europe, is that reclaimed water flows are frequently used in agricultural irrigation, especially for high water demanding crops such as certain fruits and vegetables. Due to the proximity of urban and tourist centers to irrigation enclaves (huertas), reclaimed water can offer abundant and inexpensive flows in contrast with alternative water sources (e.g. water transfers or desalinisation), provided that the quality of the effluent is sufficient for irrigation. Therefore, energy intensities may vary between areas, according to the final destination of the treated water flow. Currently, technological developments are able to bring the resulting effluents close to pre-drinkable or even drinkable quality, under the condition that there is some medium (i.e. river or aquifer) able to complete the dilution process. Indirect potable reuse, however, is still jeopardized by social acceptability, although this situation is changing as water scarcity is socially perceived as an important issue for the forthcoming years (Wester et al., 2016).

The paper is organized as follows. After the first section, a summary of the main characteristics of wastewater treatments and their energy costs, as well as the most important pieces of legislation regarding wastewater and water reuse in the EU and Spain is presented. The second section provides the results of the benchmarking, first considering European WWTPs and Mediterranean WWTPs, and second considering Catalan WWTPs and Valencian WWTPs. These results are then discussed in the light of the technology used (and the associated energy costs), but also with regard to the opportunities for reclaimed water depending on the relative strength of the different sectors of water use, including drinking water. Finally, in the conclusions the potentialities but also possible problems of the use of reclaimed water are highlighted. 


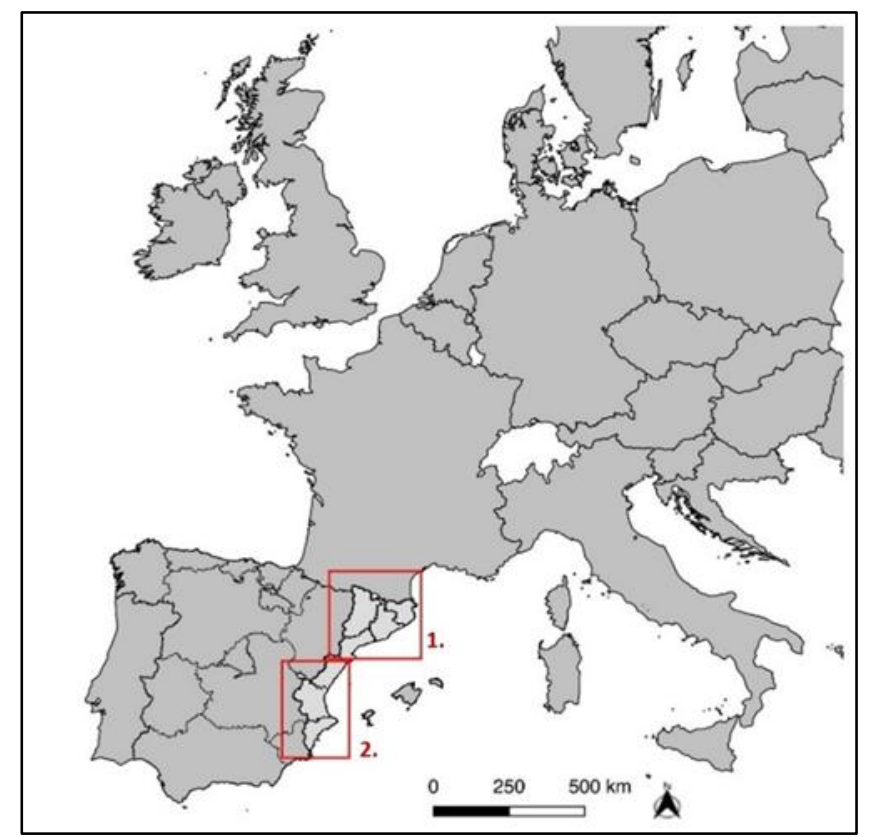

Source: own elaboration

\section{Wastewater, wastewater treatments, and recycled water}

In the Directive 91/271/EEC, the European Union (EU), defines (urban) wastewater as the mixture of domestic wastewater, industrial wastewater and/or runoff rainwater. In turn, wastewater is also defined as water of no further immediate value to the purpose for which it was used because of its quality, quantity or time of occurrence. Wastewater may have a domestic origin (as water used in toilets, bathrooms and kitchens), an industrial origin (as the water used in different manufacturing activities) or an urban origin (as runoff water circulating in cities and ending up in sewers). Wastewater is generally treated in WWTPs in order to reduce pollution loads, but sometimes is directly released to the receiving bodies (rivers, lakes, aquifers, and the sea) due to undesired events causing the saturation of the sewer network. After treatment in WWTPs, wastewater can be released into receiving bodies or can be reused for a variety of purposes, including (indirect) potable uses. Reused water, also known as reclaimed water, is therefore considered as an alternative hydrological resource if its quality parameters fit the requirements of a determined final purpose (Agència Catalana de l'Aigua, 2009).

There are two ways of re-using water: Directly, when treated water is suitable for reuse in another process or activity without any further action; or indirectly, when treated water undergoes a further process of improvement, usually by mixing with other water flows. An example of direct reuse is the usage of reclaimed water for the irrigation of public gardens, while an example of indirect reuse is the mix of reclaimed water with surface or groundwater for further process in a water purification plant. 
Depending on the type of reuse, a suitable treatment is necessary in order to comply with the regulations. Table 1 summarizes the most important pieces of legislation regarding wastewater and water reuse for the EU, Spain and the two autonomous communities of Catalonia and Valencia. EU has a directive on wastewater since 1991, but a directive on water reuse is still pending (Fawell et al., 2016) with the exception of agricultural reuse (López Peñalver, 2019).

\section{Table 1. Main legal regulations concerning wastewater and reclaimed water}

\begin{tabular}{|c|c|}
\hline European & $\begin{array}{l}\text { Directive } 2000 / 60 / E C \text { of the European Parliament and of the Council } \\
\text { establishing a framework for the Community action in the field of water policy } \\
\text { (EC, 2000). } \\
\text { COUNCIL DIRECTIVE of } 21 \text { May } 1991 \text { concerning urban waste water treatment } \\
\text { (EEC, 1991), amended by Commission Directive 98/15/EC }(*) \text { and Council } \\
\text { Directive } 2013 / 64 / E C(* *)\end{array}$ \\
\hline \multirow{3}{*}{ Spanish } & $\begin{array}{l}\text { Real Decreto 1620/2007, de } 7 \text { de diciembre, por el que se establece el } \\
\text { régimen jurídico de la reutilización de las aguas depuradas (Ministerio de la } \\
\text { Presidencia. Gobierno de España, 2007). }\end{array}$ \\
\hline & $\begin{array}{l}\text { Real Decreto Legislativo 1/2001, de } 20 \text { de julio, por el que se aprueba el texto } \\
\text { refundido de la Ley de Aguas (Ministerio De Medio Ambiente, 2001). }\end{array}$ \\
\hline & $\begin{array}{l}\text { Real Decreto } 140 / 2003 \text {, de } 7 \text { de febrero, por el que se establecen los criterios } \\
\text { sanitarios de la calidad del agua de consumo humano (BOE-Ministerio de la } \\
\text { Presidencia. Gobierno de España, 2003). }\end{array}$ \\
\hline \multirow{2}{*}{ Catalan } & $\begin{array}{l}\text { Decreto Legislativo } 3 / 2003 \text {, de } 4 \text { de noviembre, por el que se aprueba el } \\
\text { Texto refundido de la legislación en materia de aguas de Cataluña (Presidencia } \\
\text { de la Generalidad de Cataluña, 2003). }\end{array}$ \\
\hline & $\begin{array}{l}\text { Decret 83/1996, de } 5 \text { de març, sobre mesures de regularització d'abocaments } \\
\text { d'aigües residuals (Departament de Medi Ambient, 1996). }\end{array}$ \\
\hline \multirow{3}{*}{ Valencian } & $\begin{array}{l}\text { Decreto 170/1992, de } 16 \text { de octubre, del Gobierno Valenciano, por el que } \\
\text { aprueba el Estatuto de la Entidad Pública de Saneamiento de Aguas Residuales } \\
\text { de la Comunidad Valenciana (Presidencia de la Generalitat Valenciana, 1992a). }\end{array}$ \\
\hline & $\begin{array}{l}\text { Ley } 7 / 1986 \text {, de } 22 \text { de diciembre, sobre la utilización de aguas para riego } \\
\text { (Comunidad Valenciana, 1986). }\end{array}$ \\
\hline & $\begin{array}{l}\text { Ley } 2 / 1992, \text { de } 26 \text { de marzo, del Gobierno Valenciano, de saneamiento de } \\
\text { las aguas residuales de la Comunidad Valenciana. (Presidencia de la Generalitat } \\
\text { Valenciana, 1992b). }\end{array}$ \\
\hline
\end{tabular}

(*) European Community(1998). Commission Directive 98/15/EC of 27 February 1998 amending Council Directive 91/271/EEC with respect to certain requirements established in Annex I thereof. Official Journal of the European Communities. Retrieved from hittps://eur-lex.europa.eu/eli/dir/1998/15/oj

(**) European Community(2000). Council Directive 2013/64/EU of 17 December 2013 amending Council Directives 91/271/EEC and 1999/74/EC, and Directives 2000/60/EC, 2006/7/EC, 2006/25/EC and 2011/24/EU of the European Parliament and of the Council

Source: own Elaboration

The Water Framework Directive may serve as a guide for water quality requirements to achieve "good ecological status" for the water masses of the EU and, implicitly, for treated effluents as well (Kaika, 2003). In this respect, one of the main problems of the Directive 91/271 was that in urban areas only secondary treatment was made mandatory, leaving advanced tertiary treatments to 
"sensitive zones" only. This option curtailed severely the chances for reuse which, in Spain have been made dependent upon the decision of the autonomous communities. Hence, the large regional differences found in water reuse in the country.

In 2018, the EU proposed new rules to promote water reuse, but only in agricultural irrigation (European Commission 2018). In Spain, the Royal Decree RD 1620/2007 establishes different reuse activities, and their permissible thresholds associated to risks of human contact. Direct potable reuse is strictly prohibited and water reuse for agricultural irrigation is subject to strict controls. According to current legislation in Catalonia and Valencia, reclaimed water can be used for the following purposes:

- Environmental: River and wetland restoration and maintenance; groundwater recharge with the objective of creating hydraulic barriers against seawater intrusion into coastal aquifers.

- Agriculture and food production: irrigation; freshwater aquaculture.

- Urban: certain domestic uses (toilet flushing, garden irrigation, cleaning); municipal uses (irrigation of public gardens, street cleaning; hydrants).

- Industrial uses: certain production processes, cooling, cleaning.

- Leisure uses: golf courses, ornamental ponds and fountains.

Depending on the desired quality of effluents, WWTPs may apply basic or advanced processes of regeneration $(A M B, n d)$. Basic regeneration produces effluents of a sufficient quality for certain uses, for example, environmental conservation; street cleaning or cooling of thermal power plants. In other cases, more advanced treatments are necessary. If reclaimed water is to be used for agricultural irrigation, excess salts may have to be removed through electrodyalisis. Alternatively, if the destination reclaimed water is aquifer recharge, quality requirements would be even more demanding so that advanced treatment methods such as reverse osmosis would be appropriate. In sum, the range of treatments is what defines energy intensities of WWTPs. According to the desired level of quality of the final effluent, WWTPs may choose among one of the following types of treatment included in Table 2.

Wastewater treatments presented here have different energy demands. In Figure 2 it can be seen how the energy intensity of tertiary conventional technologies (filtration and disinfection) ranges between 0.04 and $0.08 \mathrm{kWh} / \mathrm{m}^{3}$ for full tertiary treatment. The later may include pumping, tertiary filtration and chlorine disinfection (low energy intensity range), and UV disinfection (instead of chlorine for the high energy intensity range). Advanced tertiary treatments require much higher energy supply - up to about $0.95 \mathrm{kWh} / \mathrm{m}^{3}$-, but still low compared to desalination processes, with demands between 1.55 and $3.17 \mathrm{kWh} / \mathrm{m}^{3}$ (Drewes et al., 2017). 


\section{Table 2. Main typologies of wastewater treatment}

\begin{tabular}{|c|c|}
\hline Artificial ponds & $\begin{array}{l}\text { Ponds are used to remove nutrients and reduce organic and pathogenic compounds. } \\
\text { There are three different types of ponds: anaerobic, facultative and aerobic. In general, } \\
\text { ponds have low operating costs and do not require energy except for small functions such } \\
\text { as mixing and pumping water. They can be effective in reducing rates of organic matter, } \\
\text { pathogens and solids. However, they also require large land areas and expert design in } \\
\text { order to avoid problems of pathogen diffusion. In addition, resulting sludge needs to be } \\
\text { treated separately (Sustainable Sanitation and \& Water Management Toolbox, 2018). } \\
\text { Ponds are considered extensive treatment systems owing to their relatively high land } \\
\text { requirements but low energy consumption (USEPA, 2016). }\end{array}$ \\
\hline Biological & $\begin{array}{l}\text { Biological treatments are intensive systems due to their high energy consumption but } \\
\text { require little land. Biological treatments usually follow physical-chemical treatment and } \\
\text { mostly use the technology of active sludge (Scholz, 2006) by which bacteria decompose } \\
\text { organic matter present in wastewater within an aerated and mixed tank where the effluent } \\
\text { is separated from the sludge (IWA, 2016). }\end{array}$ \\
\hline $\begin{array}{l}\text { Ponds + } \\
\text { Biological. }\end{array}$ & $\begin{array}{l}\text { Both ponds and biological treatments have limitations by themselves that might be } \\
\text { overcome combining the two in order to minimize energy consumption. However, } \\
\text { attaining a suitable combination remains a difficult challenge. }\end{array}$ \\
\hline $\begin{array}{l}\text { Biological + } \\
\text { Nutrient removal }\end{array}$ & $\begin{array}{l}\text { This process involves the removal of nitrogen, phosphorus or the two nutrients together } \\
\text { from wastewater to avoid risks of eutrophication in surface water and groundwater (Hu, } \\
\text { Houweling \& Dold, 2012) and comply with regulation standards or requirements } \\
\text { regarding safe levels of nutrient concentrations in effluents (Water Online, 2013). Nutrient } \\
\text { removal may be easily adapted to biological treatments since no new processes are } \\
\text { needed. The only requirement is a more complex aeration system implying higher energy } \\
\text { consumption. }\end{array}$ \\
\hline $\begin{array}{l}\text { Biological + } \\
\text { Basic tertiary } \\
\text { treatment }\end{array}$ & $\begin{array}{l}\text { It involves biological treatment with an additional final stage treatment -usually referred as } \\
\text { "tertiary". Tertiary treatments may take different configurations depending on the required } \\
\text { quality of the effluent for reuse or for discharge into a receiving body. Tertiary treatments } \\
\text { remove remaining inorganic compounds, bacteria, viruses and other pathogens harmful to } \\
\text { public health (New South Wales Government, 2010). Basic tertiary treatments solely } \\
\text { include a disinfection process using chlorine or UV. }\end{array}$ \\
\hline $\begin{array}{l}\text { Biological + } \\
\text { Advanced } \\
\text { tertiary treatment }\end{array}$ & $\begin{array}{l}\text { Advanced tertiary treatments include complex techniques such as reverse osmosis, } \\
\text { ultrafiltration, electrodyalisis, ozone, symbiotic treatment, activated carbon and ion } \\
\text { exchanges (Muralikrishna et al., 2017). Advanced wastewater treatments raise quality } \\
\text { levels to meet the highest standards and requirements currently producing an effluent of a } \\
\text { pre-potable quality. Some WWTPs combine this option with nutrient removal, according to } \\
\text { different criteria such as size, management, and geographical location. }\end{array}$ \\
\hline
\end{tabular}

Source: own elaboration 
Figure 2. Energy consumption (in $\mathrm{kWh} / \mathrm{m}^{3}$ ) according to volumes of wastewater treated and to processes of tertiary treatment, including UV disinfection; tertiary filtration; pumping water

for tertiary filtration; chlorine-based disinfection, and use of chemicals as additional reagents

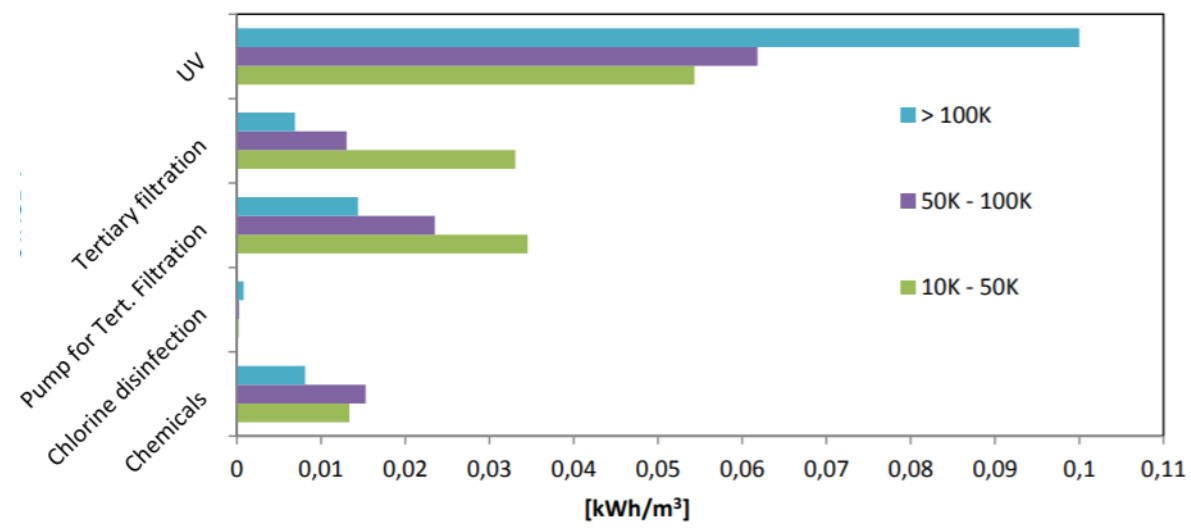

Source: ENERWATER (2015, p. 19)

\section{Methodology}

The information required for the analysis (energy consumption and treatment capacities) for both the Catalan and Valencian WWTPs, has been compiled from data by the Catalan Water Agency (ACA) and the Public Wastewater Sanitation Agency of the Valencian Community (EPSAR). Data from European WWTPs was provided by the open-access energy database developed by the H2O2O project ENERWATER (ENERWATER, 2015, 2016). The main objective of ENERWATER was to build and validate an innovative standard methodology for continuously assessing, labelling and improving the overall energy performance of European WWTPs.

For comparison purposes, ENERWATER used a benchmarking methodology. Benchmarking can be defined as the measurement of certain parameters of an organization (e.g. product, process, program) in terms of quality, performance or cost, and its comparison with the standard values or measurements of similar products, processes and programs (for its application to the water industry see Cabrera Jr. et al., 2011). This paper elaborates a benchmarking estimation of energy efficiency comparing Mediterranean WWTPs (in the coastal areas of Catalonia and Valencia) with European WWTPs, as well as the Mediterranean WWTPs among themselves. Hence, first the paper compares the energy intensities of Mediterranean WWTPs with European WWTPs. Second, it assesses the energy efficiency of Mediterranean WWTPs according to the type of treatment or technology used in their installations, bearing in mind that preliminary treatments may influence energy needs.

To assess energy efficiency, both average values and standard deviations segmented by plant capacity (after the threshold of $10,000 \mathrm{~m}^{3} /$ day) and dispersion diagrams have been used. Graphs have been developed plotting energy efficiency (expressed as $\mathrm{kWh}$ consumed/ $/ \mathrm{m}^{3}$ of wastewater 
treated) against the total volume of wastewater treated. Initially the intention was to include all WWTPs in the Spanish Mediterranean coast. However, due to data availability, the analysis is restricted to Catalonia and Valencia regions (Figure 1). Energy consumption data is presented in $\mathrm{kWh} / \mathrm{m}^{3}$ or $\mathrm{kWh} /$ year, which are standard units of measure for energy intensity in WWTPs.

\section{Analysis}

In this section the results of comparing energy intensities of European WWTPS and WWTPs of Catalonia and Valencia in the Spanish Mediterranean coast are presented. The comparison of energy intensities is established through the relationship between energy consumption $\left(\mathrm{KWh} / \mathrm{m}^{3}\right)$ and daily flows $\left(\mathrm{m}^{3} / \mathrm{d}\right)$ in each WWTP. Daily flow estimations have been obtained either from recorded registers (operational data) or from the designed flow of the plants. In figures 3 to 5 , dots and associated trend lines are the baselines to establish comparisons between each region in the Mediterranean Coast (Catalonia or Valencia) and among the technologies used in each WWTP.

Before entering in the analysis of energy intensities, table 4 shows the volumes of wastewater treated in the WWTPs of Catalonia and Valencia according to treatment type. It can be seen how total volumes are higher in Catalonia than in Valencia (reflecting mostly population differences) and that in Catalonia over a third of the wastewater is treated with the most advanced (and energy intensive) system involving biologic, nutrient removal and advance tertiary treatments with reverse osmosis. In Valencia more than 70 percent of the wastewater undergoes nutrient removal with tertiary treatment.

Table 3. Wastewater treated according to typology of treatment (cubic meters) (2016)

\begin{tabular}{|c|c|c|}
\hline Treatment & Catalonia & Valencia \\
\hline Ponds & 438,173 & 0 \\
\hline Biologic & $173,584,527$ & $5,196,754$ \\
\hline Biologic + Nutrients removal & $5,195,080$ & $5,105,287$ \\
\hline Biologic + Tertiary Treatment & $14,246,844$ & $53,788,110$ \\
\hline $\begin{array}{c}\text { Biologic + Advanced Tertiary } \\
\text { Treatment }\end{array}$ & $13,344,442$ & $18,422,748$ \\
\hline $\begin{array}{c}\text { Biologic + Nutrients removal + } \\
\text { Tertiary Treatment }\end{array}$ & $14,761,344$ & $204,607,404$ \\
\hline $\begin{array}{c}\text { Biologic + Nutrients removal }+ \\
\text { Advanced Tertiary Treatment }\end{array}$ & $102,065,158$ & $1,636,387$ \\
\hline Total & $323,635,568$ & $288,756,690$ \\
\hline
\end{tabular}

Source: European Environmental Agency (2018) 


\subsection{European WWTPs vs. Spanish Mediterranean WWTPs}

Figure 3 compares European WWTPs with Catalan and Valencian WWTPs. First, it can be seen how, in both European and Spanish Mediterranean cases, smaller WWTPs have higher energy consumptions. The trend line for Mediterranean WWTPs lies beneath the trend line for European WWTPs until the threshold of $10,000 \mathrm{~m}^{3} /$ day of flow. For higher flows, the trend changes, meaning that, on average, smaller Mediterranean WWTPs (below 10,000 $\mathrm{m}^{3} / \mathrm{d}$ ) are less energy intensive than half of the European WWTPs of similar size, but more intensive in energy when larger WWTPs are considered.

Figure 3. Benchmarking of energy intensities in Spanish Mediterranean WWTPs and European WWTPs in terms of energy consumption $\left(\mathrm{kWh} / \mathrm{m}^{3}\right)$ and average daily flow $\left(\mathrm{m}^{3} /\right.$ day)

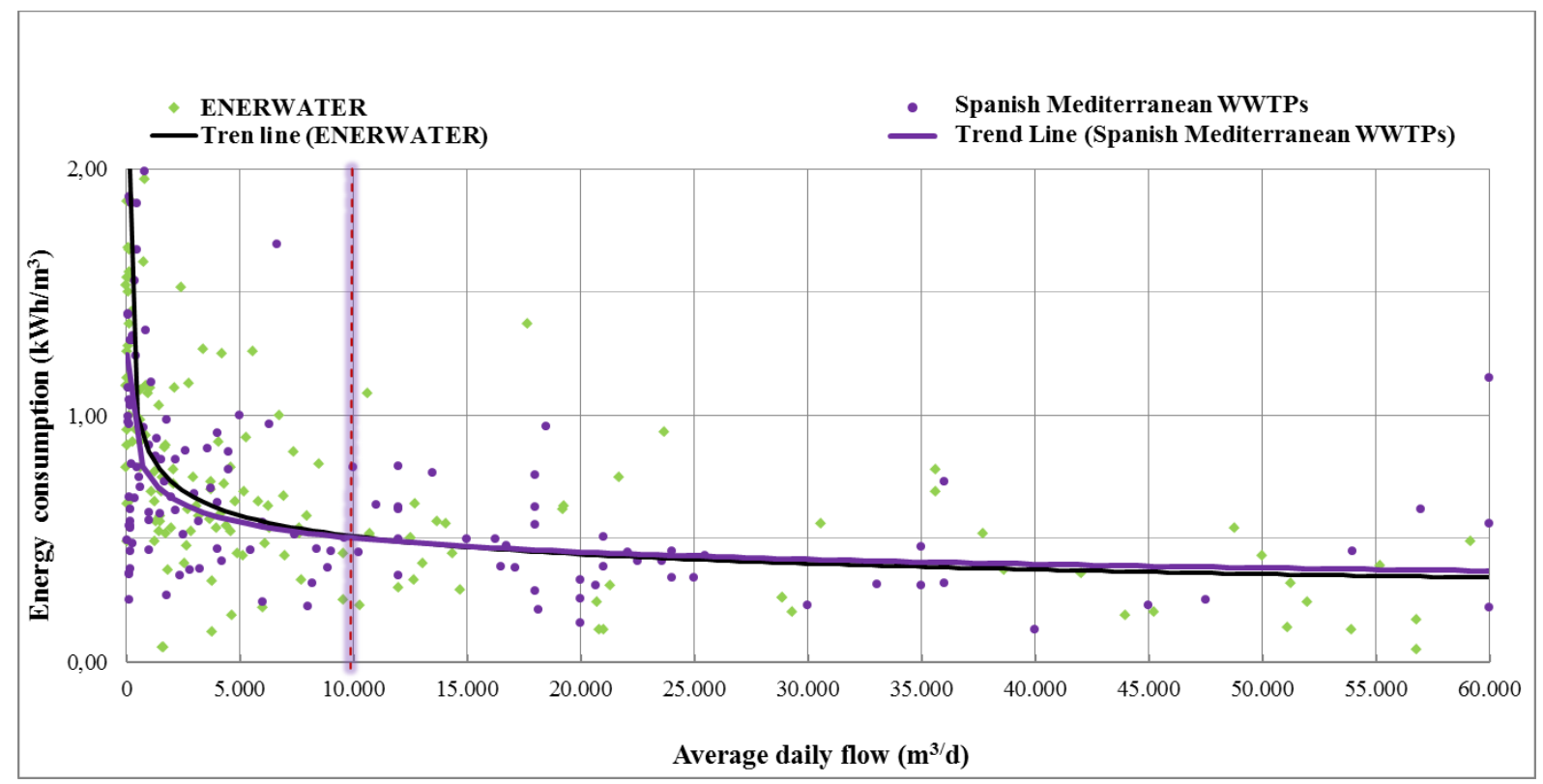

Source: own elaboration

Table 2 represents the energy intensity averages for all WWTPs in both groups separated by the $10,000 \mathrm{~m}^{3}$ /day flow threshold. Regarding the Spanish Mediterranean plants, results confirm that average consumptions and related standard deviations are higher for WWTPs with flows lower than $10,000 \mathrm{~m}^{3} /$ day $\left(0,79 \pm 0,2 \mathrm{kWh} / \mathrm{m}^{3}\right.$ in contrast with bigger WWTPs $\left(0,41 \pm 0,1 \mathrm{kWh} / \mathrm{m}^{3}\right)$. The same behavior is observed for European plants, although the later show higher energy intensities in both groups. Despite what can be deduced from trend lines in Figure 2, Table 2 indicates that larger Mediterranean WWTPs are less energy intensive than their European counterparts $(1,18 \pm$ $0,9 \mathrm{kWh} / \mathrm{m}^{3}$ and $0,52 \pm 0,5 \mathrm{kWh} / \mathrm{m}^{3}$, respectively). This behavior may be due to the analytical methods used in each case. Figure 3 depicts a regression model of all the rank of flows (without separating sections), whereas Table 4 is a more basic and simpler statistic (average and deviation) that divides WWTPs between smaller and bigger plants. Although data from Table 2 is relatively 
easy to understand, providing quick reference numbers, the most accurate comparison of energy efficiencies would be the detailed trend lines of Figure 3.

Table 4. Energy intensities $\left(\mathrm{kWh} / \mathrm{m}^{3}\right)$ of Spanish Mediterranean and European WWTPs below and above the treatment capacity threshold of $10,000 \mathrm{~m}^{3} /$ day

\begin{tabular}{|c|c|c|c|c|c|}
\hline \multicolumn{3}{|c|}{ Spanish Mediterranean WWTPs } & \multicolumn{3}{|c|}{ European WWTPs } \\
\hline Rank & $\begin{array}{l}<10,000 \\
\mathrm{~m}^{3} / \text { day }\end{array}$ & $\begin{array}{c}>10,000 \\
m^{3} / \text { day }\end{array}$ & Rank & $\begin{array}{l}<10,000 \\
\mathrm{~m}^{3} / \text { day }\end{array}$ & $\begin{array}{c}>10,000 \\
\mathrm{~m}^{3} / \text { day }\end{array}$ \\
\hline \# WWTPs & 90 & 53 & \# WWTPs & 124 & 63 \\
\hline $\begin{array}{c}\text { Average } \\
\text { consumption } \\
\pm S T\end{array}$ & $1.00 \pm 1,0$ & $0.44 \pm 0,2$ & $\begin{array}{c}\text { Average } \\
\text { consumption } \pm \\
\text { ST }\end{array}$ & $1.18 \pm 0,9$ & $0.52 \pm 0,5$ \\
\hline $\begin{array}{l}\text { Standard } \\
\text { deviation } \\
\text { (ST) }\end{array}$ & 0.99 & 0.20 & $\begin{array}{c}\text { Standard } \\
\text { deviation (ST) }\end{array}$ & 0.92 & 0.48 \\
\hline
\end{tabular}

Source: own elaboration

\subsection{Catalan WWTPs vs Valencian WWTPs}

Comparisons between each Spanish Mediterranean region and European averages yield also interesting results (Figures 4 and 5). With the Catalan trend line located above the European trend line from $5000 \mathrm{~m}^{3}$ /day onwards, it can be deduced that, on average, Catalan WWTPs are more energy intensive than European WWTPs. However, the trend for Valencia is the opposite (Figure 5). On average, smaller Valencian WWTPs (until 10,000 $\mathrm{m}^{3} /$ day) are less energy intensive than European WWTPs, but above this flow, they become more intensive, following the pattern described in Figure 3.

Figure 4. Benchmarking of energy intensities between Catalan WWTPs and European WWTPs in terms of energy consumption in $\mathrm{kWh} / \mathrm{m}^{3}$ and average daily flow in $\mathrm{m}^{3} /$ day

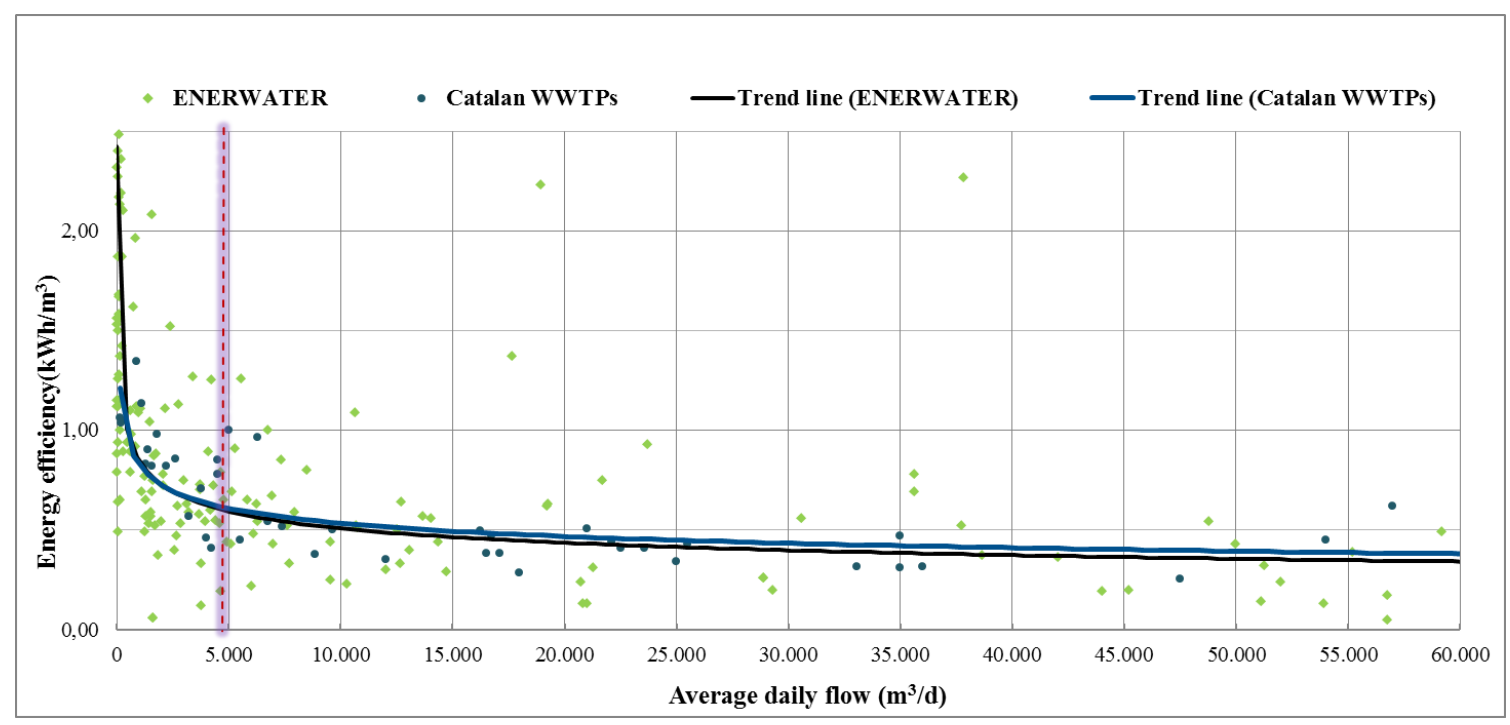

Source: own elaboration 
Figure 5. Benchmarking comparison of energy intensities between Valencian WWTPs and European WWTPs in terms of energy consumption in $\mathrm{kWh} / \mathrm{m} 3$ and average daily flow in $\mathrm{m} 3 /$ day

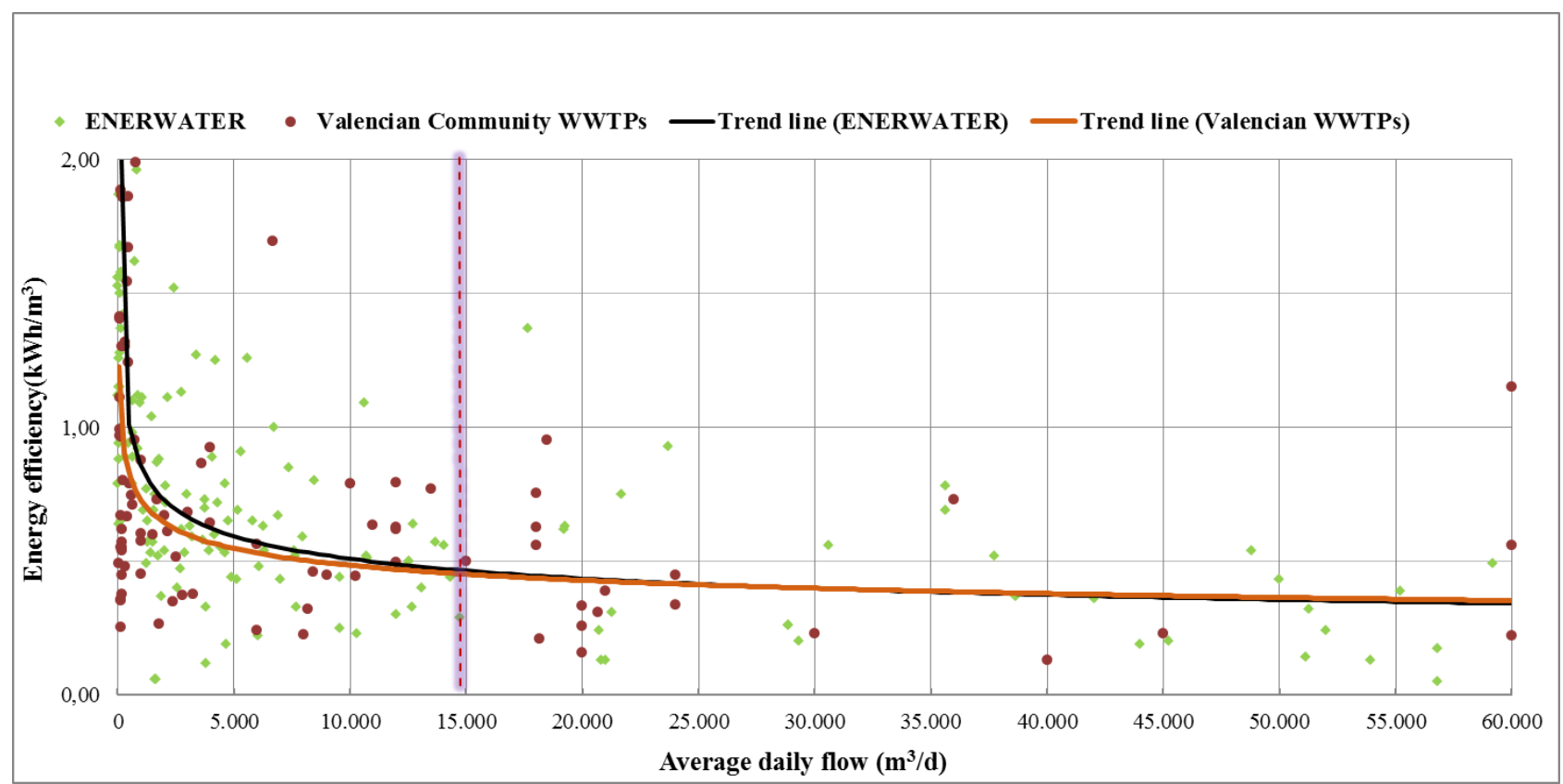

Source: own elaboration

Table 5. Energy intensities $\left(\mathrm{kWh} / \mathrm{m}^{3}\right)$ of Catalan and Valencian WWTPs

\begin{tabular}{|c|c|c|c|c|c|}
\hline \multicolumn{3}{|c|}{ Catalan WWTPs } & \multicolumn{3}{c|}{ Valencian WWTPs } \\
\hline Rank & $<10,000 \mathrm{~m} 3 /$ day & $\begin{array}{c}>10,000 \\
\mathrm{~m} 3 / \text { day }\end{array}$ & Rank & $<10,000 \mathrm{m3} /$ day & $\begin{array}{c}>10,000 \\
\mathrm{~m} 3 / \text { day }\end{array}$ \\
\hline $\begin{array}{c}\# \\
\text { WWTPs }\end{array}$ & 24 & 22 & \#WWTPs & 66 & 31 \\
\hline $\begin{array}{c}\text { Average } \\
\pm \text { ST }\end{array}$ & $0.79 \pm 0,2$ & $0.41 \pm 0,1$ & $\begin{array}{c}\text { Average } \pm \\
\text { ST }\end{array}$ & $1.08 \pm 0,2$ & $0.47 \pm 0,2$ \\
\hline $\begin{array}{c}\text { Standard } \\
\text { deviation } \\
\text { (ST) }\end{array}$ & 0.26 & 0.09 & $\begin{array}{c}\text { Standard } \\
\text { deviation } \\
\text { (ST) }\end{array}$ & 1.14 & 0.25 \\
\hline
\end{tabular}

Source: own elaboration

A comparison between the two Spanish Mediterranean areas is presented in Table 5. Small and large Catalan WWTPs, according to averages and standard deviations, appear to be less energy intensive than Valencian WWTPs. However, direct comparison in this case may be misleading, because in Catalonia the number of WWTPs treating less than 10,000 $\mathrm{m}^{3} /$ day is about a third of their equivalent in Valencia.

In order to understand better the energy efficiency of WWTPs in both areas, a histogram of these plants based on the flow treated is provided (Figure 6). Average daily flows from the WWTPs in both regions are aggregated into intervals. In Catalonia, only $24 \%$ of the WWTPs have a flow equal or lower than 3,000 $\mathrm{m}^{3} /$ day, whereas in Valencia WWTPs of this dimension represent 55 percent of the total. From the histogram, it can be inferred that in Valencia small WWTPs tend to be 
more widespread, whereas Catalonia is characterised by a more centralised model based on more uniform WWTPs.

Figure 6. Histogram of flow ranks for Catalan and Valencian WWTPs

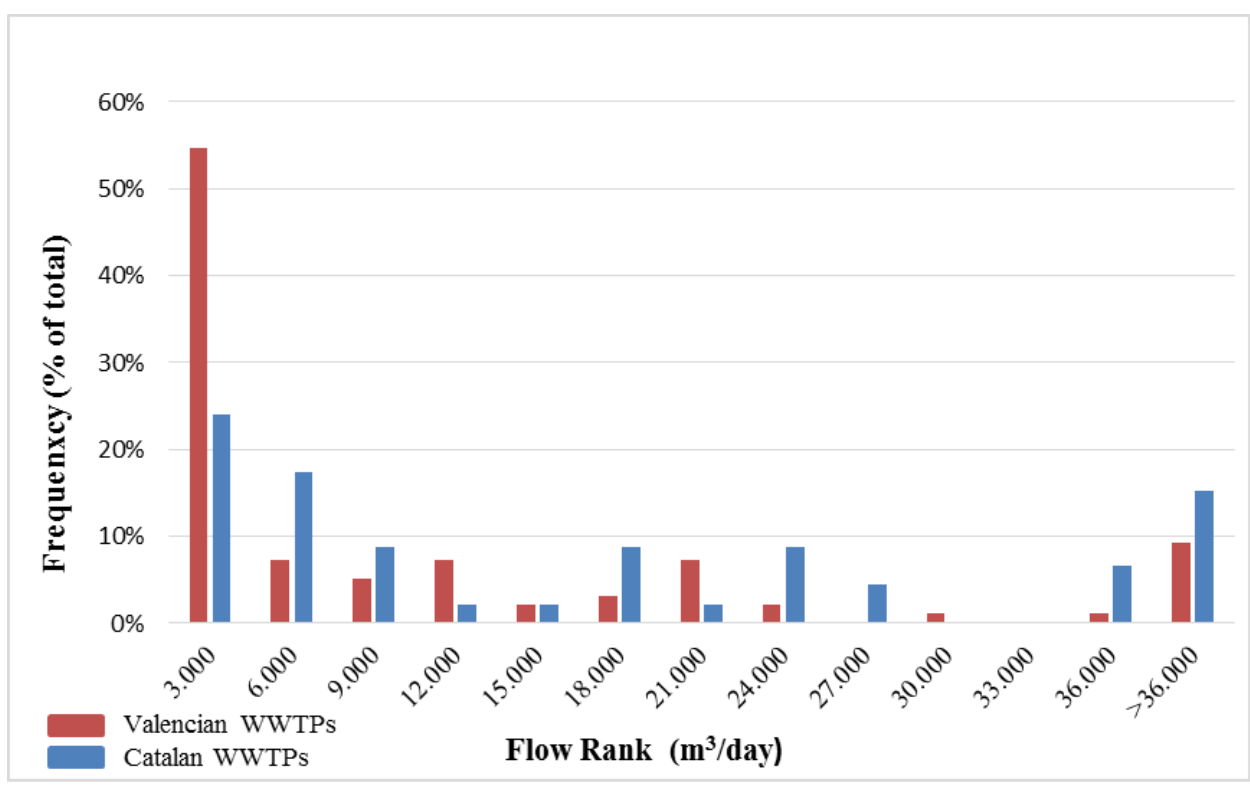

Source: own elaboration

\subsection{Energy requirements of Spanish Mediterranean WWTPs}

Unfortunately the ENERWATER database does not discriminate plants according to the main type of technology used. Hence in this section we will comment on the energy consumption of different treatments taking into account the Spanish Mediterranean plants only.

Table 6 classifies the Catalan and Valencian WWTPs included in our database according to the type of treatment. Average water flows and average energy consumption (in $\mathrm{kWh} / \mathrm{m}^{3}$ ) are also indicated. For some treatments (ponds, ponds +biologic, and biologic plus advanced tertiary) figures should be taken with caution due to the very small number of WWTPs in each of these categories. Still, it can be seen how simpler treatments such as ponds are also those with less energy consumption and more complex treatments such as biologic with nutrient removal and an advanced tertiary treatment, have the higher energy intensities. However, some treatments record lower consumptions despite their complexity, meaning that other factors such as economies of scale may be present. 
Table 6. Number, average flow, and energy consumption of Spanish Mediterranean WWTPs according to type of treatment

\begin{tabular}{|c|c|c|c|c|c|}
\hline TOTAL & $\begin{array}{c}\# \\
\text { WWTPs }\end{array}$ & $\begin{array}{c}\text { Average } \\
\text { Water Flow } \\
\text { (m3/day) }\end{array}$ & $\begin{array}{c}\text { Standard } \\
\text { deviation }\end{array}$ & $\begin{array}{c}\text { Energy } \\
\text { Consumption } \\
(\mathrm{kWh} / \mathrm{m} 3)\end{array}$ & $\begin{array}{c}\text { Standard } \\
\text { deviation }\end{array}$ \\
\hline Ponds & 4 & 3,302 & 3.095 & 0.715 & 0.58 \\
\hline Biologic & 16 & 32,775 & 103.873 & 0.725 & 0.32 \\
\hline Ponds + Biologic & 1 & 2,000 & - & 0.344 & - \\
\hline $\begin{array}{c}\text { Biologic + Nutrients } \\
\text { removal }\end{array}$ & 16 & 2,617 & 4.555 & 1.268 & 0.74 \\
\hline $\begin{array}{c}\text { Biologic + Tertiary } \\
\text { Treatment }\end{array}$ & 29 & 11,292 & 24.519 & 1.107 & 1.53 \\
\hline $\begin{array}{c}\text { Biologic + Advanced } \\
\text { Tertiary Treatment }\end{array}$ & 1 & 44,833 & 31.585 & 0.35 & 0.06 \\
\hline $\begin{array}{c}\text { Biologic + Nutrients } \\
\text { removal + Tertiary } \\
\text { Treatment }\end{array}$ & 62 & 16,536 & 28.281 & 0.58 & 0.34 \\
\hline $\begin{array}{c}\text { Biologic + Nutrients } \\
\text { removal + advanced } \\
\text { Tertiary Treatment }\end{array}$ & 4 & 123,567 & 199.565 & 1.397 & 1.14 \\
\hline
\end{tabular}

Source: own elaboration

Figures 7, 8 and 9 represent the energy cost of each treatment in relation to the average daily flow of wastewater treated. Figure 7 shows how energy consumption in the case of ponds decreases rapidly and approaches zero when flows to be treated increase, thus corroborating the relevance of the economies of scale. The combined technology of ponds plus biologic treatment appears to be more efficient than ponds alone. However, the results should be taken with caution due to the very low number of plants in this group.

Figure 8 compares biological treatments with biological treatments plus nutrient removal. It can be seen how in this case the size of WWTPs is inversely related to their energy consumption. Thus, for flows less than $5,000 \mathrm{~m}^{3} /$ day, basic biologic treatments are less energy intensive than these treatments combined with the removal of nutrients. However, this trend is reversed for larger WWTPs.

Figure 9 depicts the effect of different tertiary treatments on energy intensity. Conventional tertiary treatments are more common among WWTPs and also less energy intensive than advanced tertiary treatments. The fact that advanced tertiary treatments are more energy intensive and therefore more expensive may explain their relatively small numbers. 
Figure 7. Energy Intensity of Ponds and of Ponds + biologic treatments.

Spanish Mediterranean WWTPs

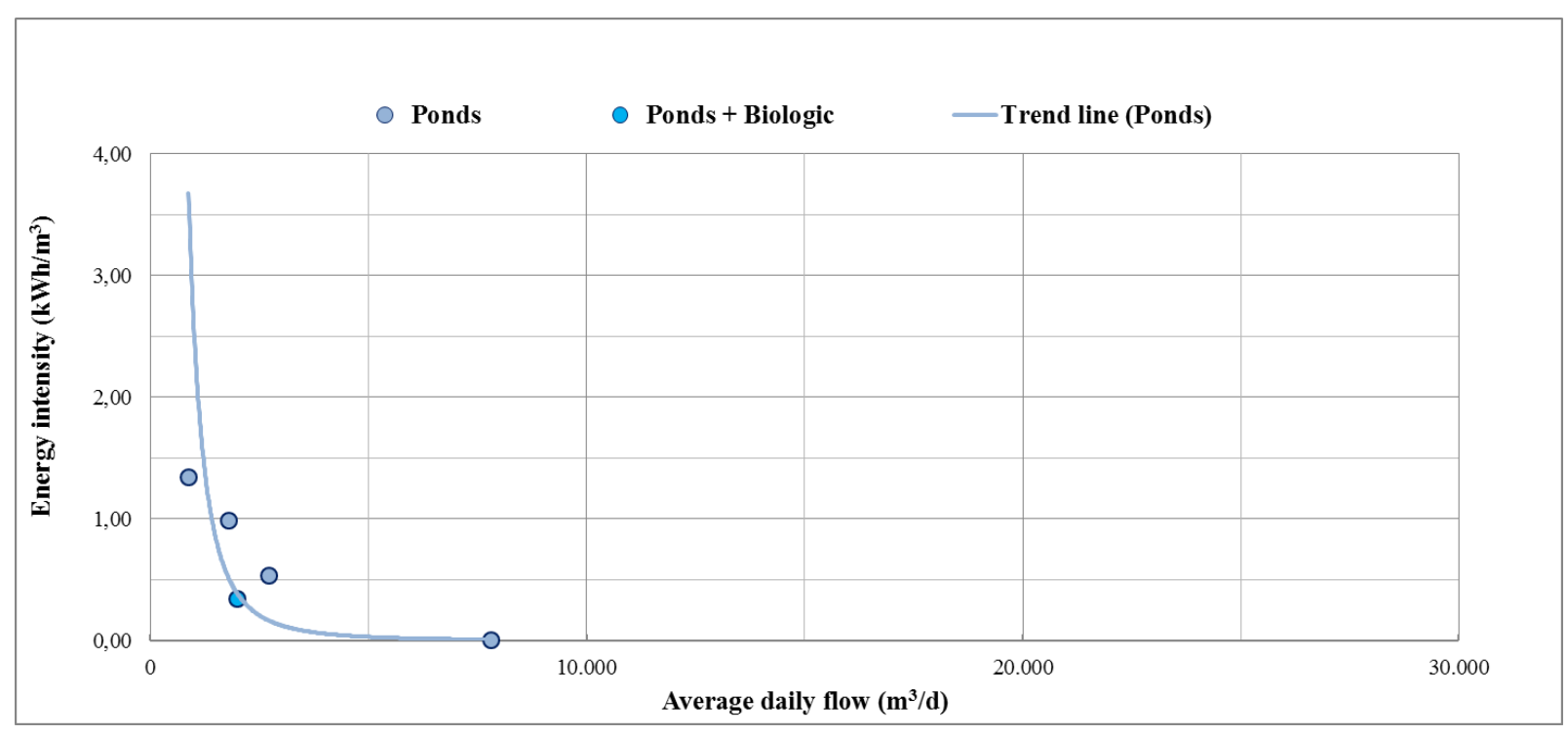

Source: own elaboration

Figure 8. Energy Intensity of Biologic and of Biologic and Nutrient Removal treatments.

\section{Spanish Mediterranean WWTPs}

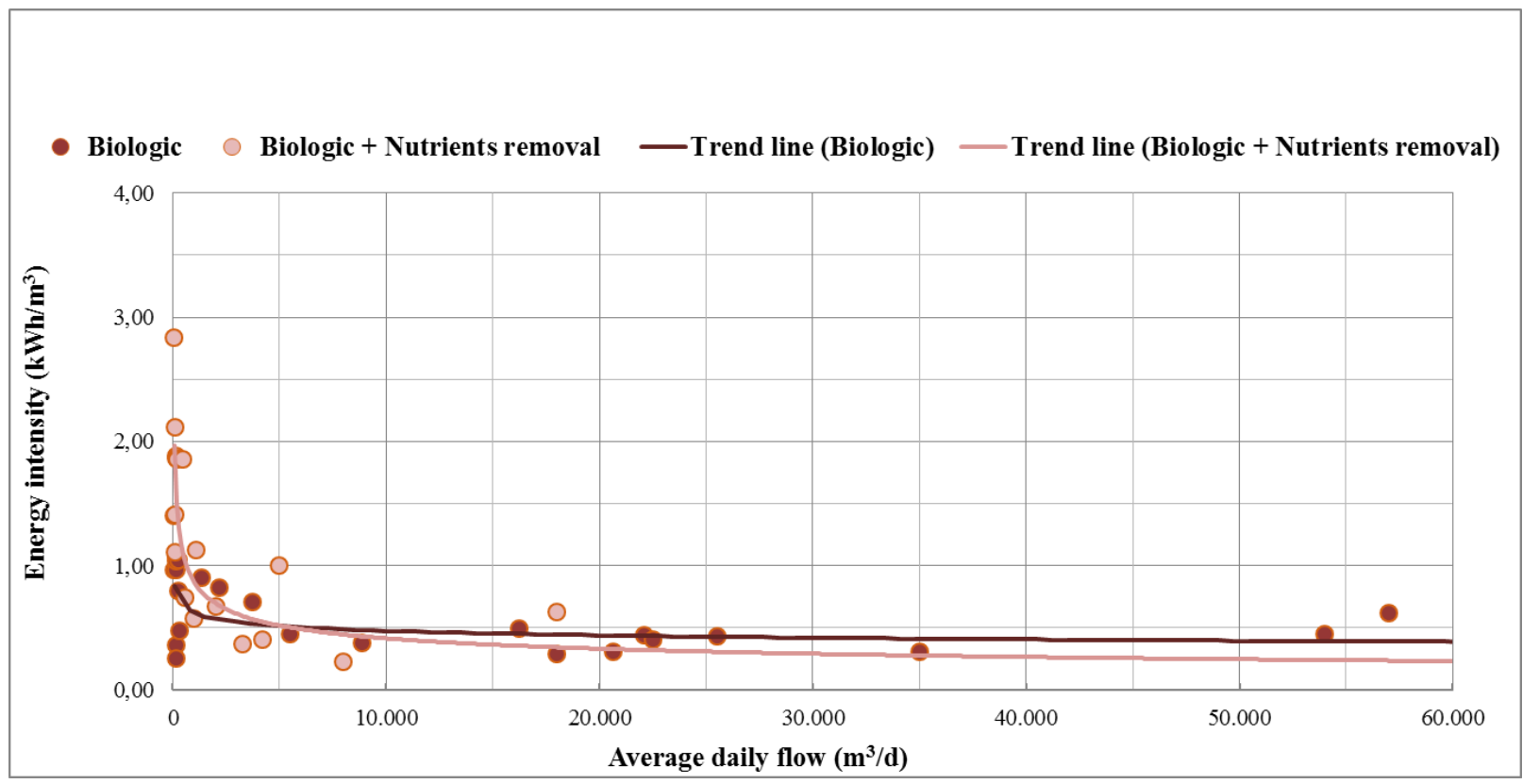

Source: own elaboration 


\section{Figure 9. Energy Intensity of Biologic with Basic Tertiary Treatment and of Biologic with Advanced Tertiary Treatment. Spanish Mediterranean WWTPs}

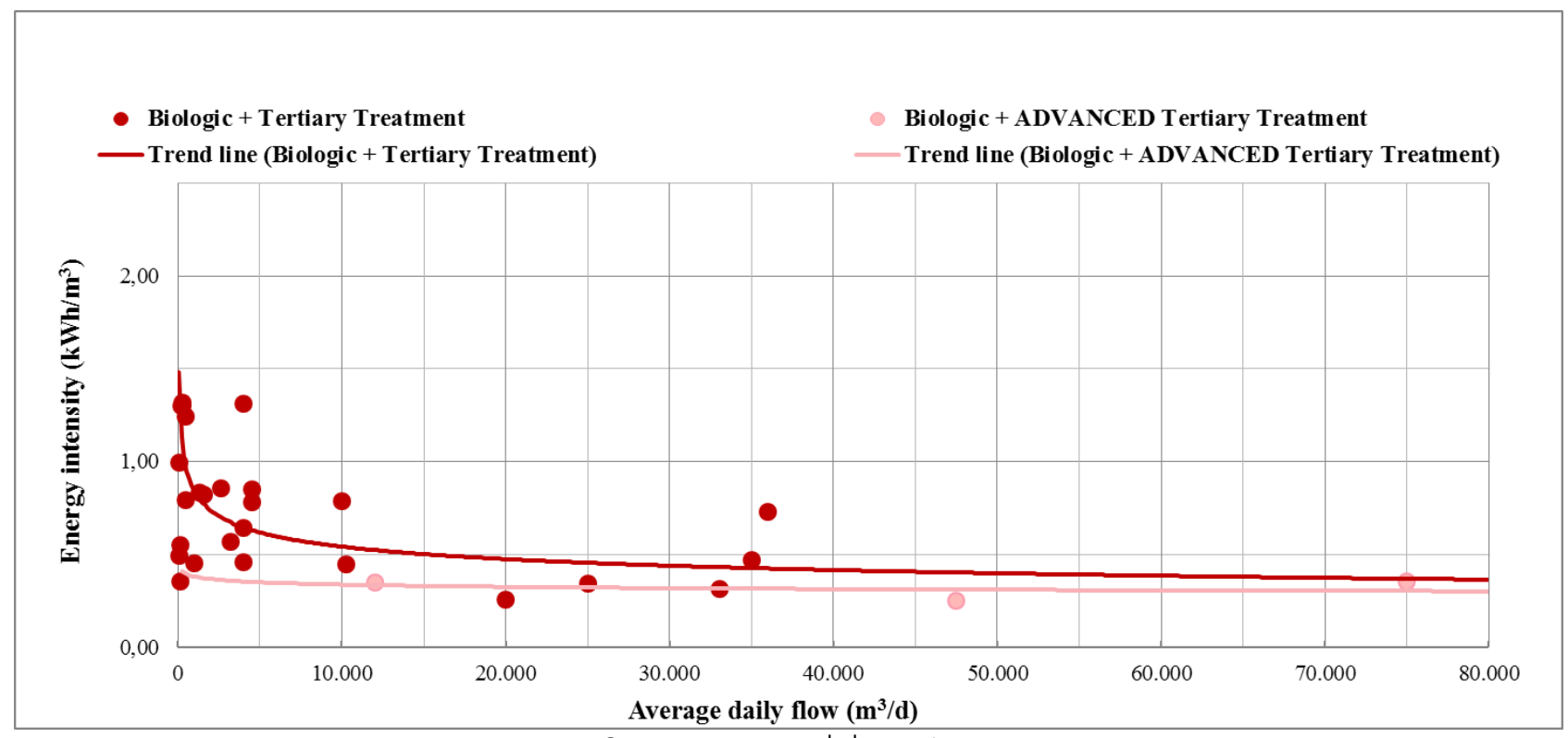

Source: own elaboration

Finally, Figure 10 compiles average energy consumption of the Spanish WWTPs for all the technologies commented above. The numbers next to each dot represent WWTPs using each type of technology. The distribution of points indicates that more complex treatments are less common and limited to large WWTPs. For flows above 10,000 $\mathrm{m}^{3} /$ day, WWTPs incorporate tertiary treatments, whereas simplest treatments like ponds tend to be more common in small WWTPs. We have evaluated in particular the effects of nutrient removal. As observed by looking at the trend model, the relation of the $X$ and $Y$ axis is not lineal. Therefore, in order to compare more adequately trends in energy efficiency, the trend line has been translocated for each case, as exemplified in Figure 10 by the red line. Here this line represens the translocation of the trend model for the Cluster of 29 WWTPs with biologic and tertiary treatment.

From a technical perspective, nutrient removal technologies usually imply the need to introduce mechanically air into the wastewater. Hence, energy demanding equipment such as air bubblers is required. As observed in Figure 8, relatively small WWTPs with nutrient removal processes are more energy intensive than those with simple removal of organic matter using biological means. The reversal of trends for WWTPs treating more than $10,000 \mathrm{~m}^{3} / \mathrm{d}$ may be explained by the implementation of energy optimisation processes only in those WWTPs with nutrient removal.

On the other hand, advanced tertiary treatments are more energy intensive than conventional tertiary treatments, as observed in Figure 9. Such difference responds to the fact that advanced tertiary treatments imply the use of certain technologies that require mechanical or electrical energy to further separate undesirable components of wastewater (i.e ozonation or reverse osmosis). Besides, 
in conventional tertiary treatments, the technology only requires chemical usage and simple types of filtration.

As observed in Figure 10, the addition of both nutrient removal and tertiary treatment processes increase the energy intensity of WWTPs. This fact, combined with scaling effects that further increase energy requirements for higher capacity WWTPs, has become the main motivation for the implementation of energy optimisation strategies in these plants. Such strategies imply that some of the highest capacity WWTPs may be less energy demanding than expected. In sum, energy consumption needs to be modulated according to volumes of effluent treated.

Figure 10. Number of WWTPs and Average Energy Intensities of different treatments. Spanish Mediterranean WWTPs

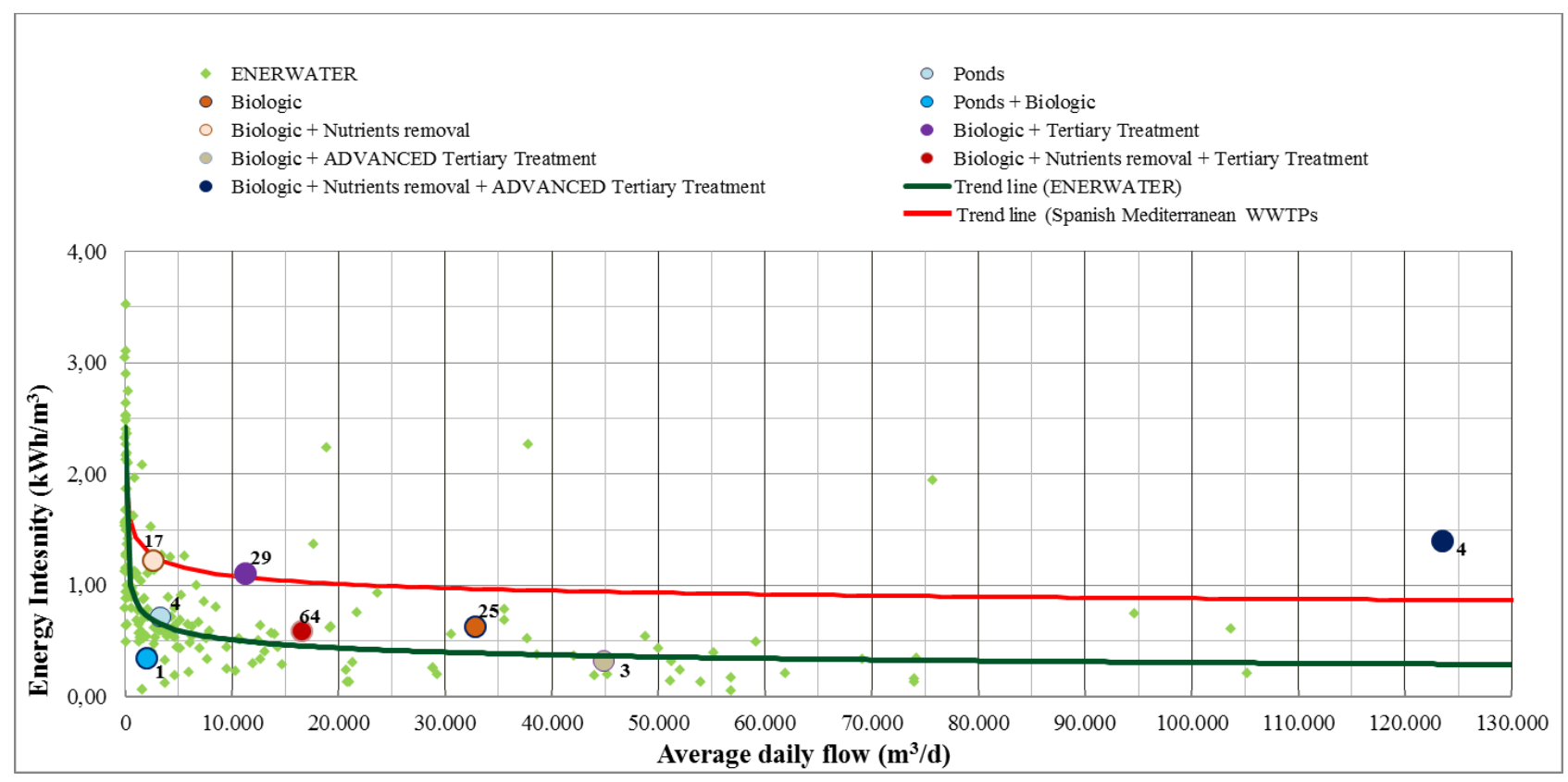

Source: own elaboration

Regarding the geographical distribution of Spanish Mediterranean WWTPs, some differences between Catalonia and Valencia are worth noting. Figure 11 (Maps A and B) show the current state of wastewater treatment per municipality in Catalonia and Valencia. In green colour we represent those municipalities which do not have any WWTP within their municipal limits. Accordingly, their wastewater is treated in WWTPs located in other municipalities. This is common alternative for metropolitan systems such as that of Barcelona. Yellow-coloured municipalities represent those having one or more WWTPs within their municipal limits, treating their own wastewater as well as that of other municipalities. The two maps only display the physical presence of WWTPs. Greencoloured municipalities are more frequent in Catalonia, reinforcing our hypothesis that wastewater treatment in Catalonia follows a more centralised pattern than in Valencia. 
Maps C and D represent WWTPs characteristics. The bigger the circles are, the more volume of water is treated in each WWTP. However, circles size must be considered along with their colour, which represents the number of WWTPs. Thus a large blue circle probably represents a metropolitan WWTP. On the other hand, smaller blue circles mean individual WWTPs, more characteristic of decentralized systems.

Catalan WWTPs with blue and pink colours depict the class of 1 to 5 WWTP in each municipality with at least one WWTP (green-coloured on the right map). The larger circles are found in the Metropolitan Area of Barcelona (AMB) because of the presence of the big metropolitan WWTPs of El Prat del Llobregat and Besòs. In Catalonia this pattern of relatively large WWTPs is more or less repeated in the Girona province, although not with the same size (>100,000 $\mathrm{m}^{3} /$ day). Towards the south, in the province of Tarragona, smaller WWTPs are more frequent reproducing a situation more akin to that of Valencia. In sum, the Catalan pattern of WWTPs shows a predominantly centralised system, based on large units that treat wastewaters from different municipalities. These plants often use complex, energy demanding treatment technologies due to the often highly polluted wastewater entering the plants and the high quality requirements for effluents. However, in compensation, economies of scale may reduce substantially unitary energy costs.

In the Valencian Community, almost every municipality has a WWTP (Map B, in yellow). Here we also find large circles but with different colours. Pink, orange and even red coloured- circles are more frequent, meaning that bigger circles represent a large quantity of water flow but shared among several WWTPs in the same municipality.

Together with the presence of medium and smaller circles, this creates a more decentralized pattern. 
Figure 11. Catalonia and Valencia WWTPs according to municipalities, number and size
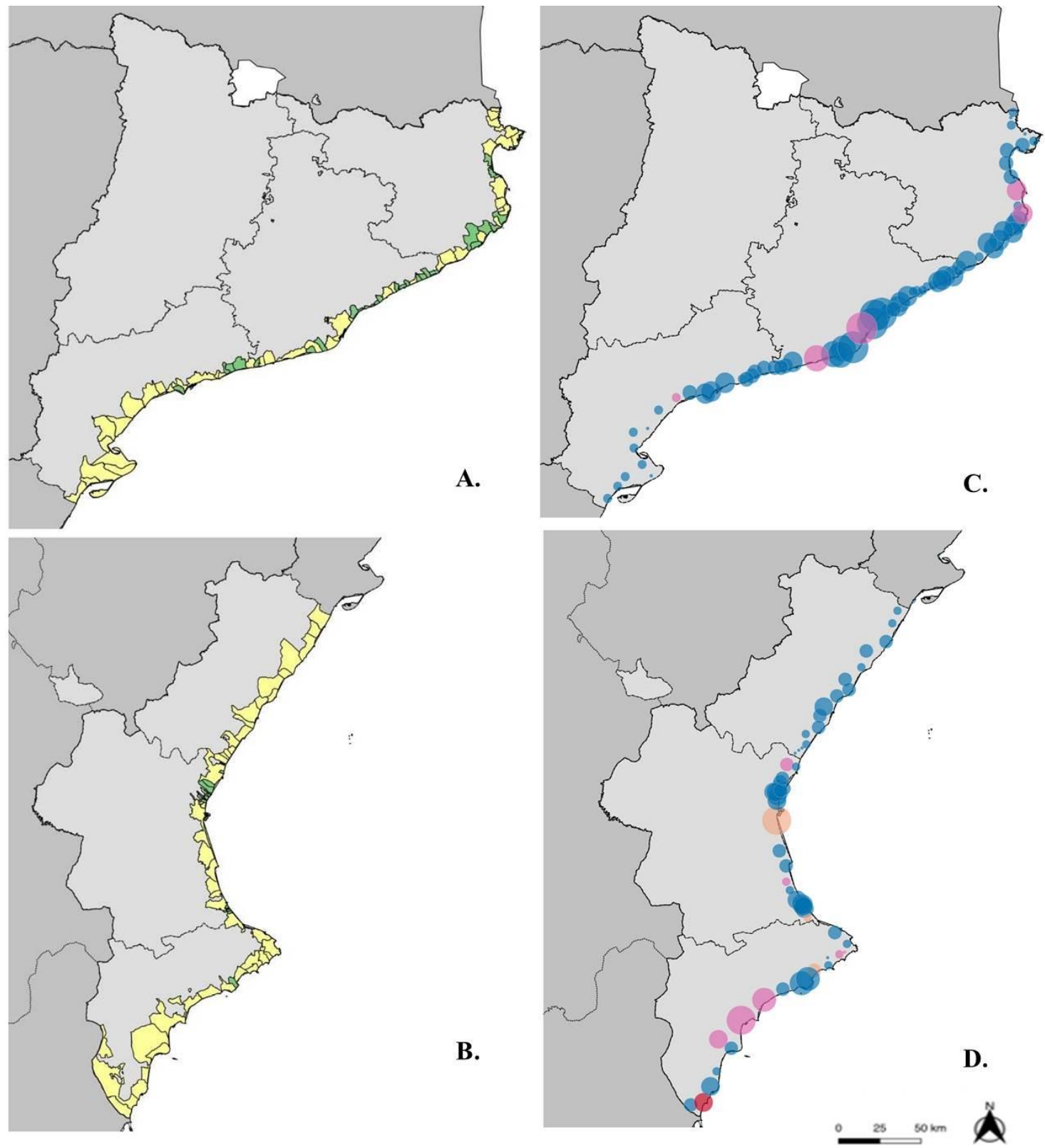

\section{Legend}

Mediterranean Municipalities

$\square$ Treats WW in plants not located in the municipality

WWTPs size by intervals

- $\quad<3.000 \mathrm{~m} 3 /$ day

- $3.000-12.000 \mathrm{~m} 3 / \mathrm{day}$

$12.000-30.000 \mathrm{~m} 3 /$ day

$30.000-60.000 \mathrm{~m} 3 /$ day

( $60.000-100.000 \mathrm{~m} 3 /$ day

$>100.000 \mathrm{~m} 3 /$ day

1-2 Number of WWTPs

3-5 Number of WWTPs

6-10 Number of WWTPs

- $>10$ Number of WWTPs

Source: own elaboration 


\subsection{Water Reuse}

In Table 7. Catalan and Valencian WWTPs are classified according to the destination of treated effluents. Although it has not been possible to obtain data for the specific flows treated for each category, the table shows how in more than half of Valencian WWTPS agricultural irrigation is the final destination of reclaimed water while in Catalonia uses of this resource are more varied. If any, environmental and urban uses somehow appear to stand up a little above the rest. On the other hand, Catalan WWTPs appear to supply reclaimed water to a large variety of uses than Valencian WWTPS in which irrigation is almost always present.

Table 7. Number of WWTPs according to the final destination of treated wastewater

\begin{tabular}{|c|c|c|}
\hline Destination & Catalonia & Valencia \\
\hline Leisure & 9 & 2 \\
\hline Agricultural & 8 & 35 \\
\hline Environmental & 11 & 3 \\
\hline Industrial & 4 & 1 \\
\hline Urban & 12 & 8 \\
\hline Agricultural + Leisure & 1 & 0 \\
\hline $\begin{array}{l}\text { Agricultural }+ \\
\text { Environmental } \\
\end{array}$ & 1 & 2 \\
\hline Agricultural + Urban & 1 & 4 \\
\hline Environmental + Leisure & 1 & 0 \\
\hline Urban + Environmental & 1 & 0 \\
\hline Urban + Industrial & 1 & 0 \\
\hline Urban + Leisure & 2 & 0 \\
\hline $\begin{array}{c}\text { Agricultural + } \\
\text { Environmental }+ \\
\text { Industrial }\end{array}$ & 0 & 1 \\
\hline $\begin{array}{c}\text { Agricultural + } \\
\text { Environmental + Urban }\end{array}$ & 1 & 0 \\
\hline $\begin{array}{c}\text { Agricultural + Leisure + } \\
\text { Urban }\end{array}$ & 1 & 2 \\
\hline $\begin{array}{c}\text { Environmental + } \\
\text { Industrial + Urban }\end{array}$ & 2 & 0 \\
\hline $\begin{array}{c}\text { Environmental + Leisure } \\
+ \text { Urban }\end{array}$ & 1 & 0 \\
\hline $\begin{array}{c}\text { Agricultural + } \\
\text { Environmental }+ \text { Urban }+ \\
\text { Industrial }\end{array}$ & 1 & 0 \\
\hline
\end{tabular}

Source: own elaboration 


\section{Discussion}

Two broad trends can be discerned from the results of the analysis. First, the analysis showed that the smaller the WWTP is, the higher its energy intensity regardless of the technology used. Second, generally more complex technology treatments imply higher energy consumptions, although in some cases, extra treatments may not necessarily lead to this conclusion. This can be explained either because of insufficient data or because the application of technology optimization processes. According to the results presented here, the combination of biological processes, nutrient removal and advanced tertiary treatments would require the maximum energy intensity. On the other hand, simpler processes such as ponds or the combination of these with basic biological treatment would produce the lowest energy requirements.

An interesting point is whether large, metropolitan WWTPs, such as those in Barcelona or Valencia, have any relation with energy intensity. Table 7 shows energy intensity data for WWTPs, comparing Barcelona and Valencia. The table summarises the total treated water per day and the total energy consumption per day for these plants. Both Catalonia and Valencia register similar average energy intensity, but these intensities are not homogeneously distributed and outside their respective metropolitan areas, differences are noticeable. In Catalonia there are two large WWTPs treating 58 percent of all water and consuming 55 percent of the total energy. However, in Valencia the two biggest WWTPs produce just 26 percent of the treated wastewater and 12 percent of the total energy consumed. Hence, data reflect a more centralised wastewater treatment system in Catalonia versus a more decentralised model for Valencia. Besides, the centralization of wastewater treatment appears to be correlated with the population served. As noted previously, smaller WWTPs tend to be more energy intensive than larger WWTPs. Since decentralized systems have a higher presence of small WWTPs, these results could lead to the conclusion that decentralised systems may be more energy intensive than centralised systems. However, if all coastal WWTPs of both regions are taken into account, energy intensity is similar for both areas. This could be explained by the distorting effect of the few but large metropolitan WWTPs serving the metropolitan populations of Barcelona and Valencia. However, when these metropolitan WWTPs are not taken into account, data shows that Catalan WWTPs tend to be slightly less energy intensive than Valencian WWTPs (Table 8).

The distorting effect of metropolitan WWTPs can be explained by the following factors. First the Metropolitan WWTPs of Valencia use sludge for cogeneration purposes. Hence, they compensate energy consumption with the production of biogas. In contrast, only one Catalan Metropolitan WWTP in the group performs cogeneration with sludge. Second, Valencian Metropolitan WWTPs operate with simpler treatments than Catalan WWTPs. The two Valencian WWTPs use UV disinfection technology to treat wastewater. No more additional treatments are needed because the final use of reused wastewater is irrigation, which has quality requirements less demanding than 
other uses. Additionally, one of the Catalan WWTPs operates with reverse osmosis, an intensive and complex technology requiring high energy inputs but capable to produce an effluent of pre potable quality.

\section{Table 8. Energy Intensity of Catalan and Valencian WWTPs with and without metropolitan plants}

\begin{tabular}{|c|c|c|c|c|c|c|}
\cline { 2 - 7 } \multicolumn{1}{c|}{} & \multicolumn{3}{c|}{ With Metropolitan WWTPs } & \multicolumn{3}{c|}{ Without Metropolitan WWTPs } \\
\cline { 2 - 7 } & $\begin{array}{c}\text { Total } \\
\mathrm{m}^{3} / \text { day }\end{array}$ & Total $\mathrm{kWh} /$ day & $\mathrm{Kwh} / \mathrm{m}^{3}$ & Total $\mathrm{m}^{3} /$ day & $\begin{array}{c}\text { Total } \\
\mathrm{kWh} / \text { day }\end{array}$ & $\mathrm{Kwh} / \mathrm{m}^{3}$ \\
\hline CATALONIA & $1,629.908$ & 678,383 & 0.42 & 684,908 & 308,865 & 0.45 \\
\hline VALENCIA & $1,247.181$ & 526,675 & 0.42 & 922,381 & 461,364 & 0.50 \\
\hline
\end{tabular}

Source: own elaboration

The final configuration of wastewater treatment systems is the product of many different and interrelated factors, including the amount and pollution loads of wastewater (in turn related to population and dominant economic activities); type and intensity of treatments; cost, and the final destination of the effluent. Regarding the latter, possibilities for using reclaimed water also depend on the economic and social geography of different areas. Thus, the important presence of reclaimed water in the Valencian portfolio of water resources obeys to the relevance of these flows for irrigation (Aznar-Crespo et al., 2019). Valencia uses over 45 percent of reclaimed water flows for agricultural purposes to the point that, along with Cyprus, this region and the neighbouring region of Murcia (using for agriculture an ever higher proportion of reclaimed water) probably concentrate much of water reuse in Europe, at least concerning productive activities (Kellis et al., 2013). This is facilitated by the relative proximity between urban areas and irrigation perimeters, a long tradition of agricultural water reuse because of the uncertainties associated with more conventional water resources, and the subsequent need of accessing all water flows to minimize scarcity risks.

The quality requirements of reclaimed water addressed to irrigation appear to be acceptable for farmers given the fact that, in the analysis presented here, Valencian WWTPs do not generally apply complex, energy intensive technologies. Most of the reclaimed water, sometimes mixed with water of other origins (streams or aquifers) is used for the irrigation of fruit orchards or other crops not implying direct contact between the reclaimed water and the foodstuff produced. Farmers would prefer surface water but, in turn, reclaimed water is a better choice for them since it is much cheaper than desalinated water (Aznar-Crespo et al., 2019). In some cases, however, energy intensive processes are required for agricultural uses. For example, in the Marina Baja area, located in the Alicante coast of the Valencia region, wastewater produced by the large tourist resort of Benidorm is treated in a conventional WWTP but undergoes a post-process of desalination for its final use in the irrigation of fruit orchards in nearby agricultural areas. Due to the fact that many 
hotels in Benidorm use water with a relatively high salt content for non-potable purposes, and that part of this water reaches the city sewer system, wastewater arriving at the plant is highly saline, making traditional treatments insufficient. Hence, water must be retreated to reduce it salt content through reverse osmosis. The two combined treatments are the result of an agreement between the regional water company Consorcio de Aguas de la Marina Baja and several irrigation communities by which the later, during drought periods, provide the former with clean water from aquifers and reservoirs to supply Benidorm and other tourist centers, in exchange for reclaimed water. Despite this has been obtained after a difficult process of negotiation between farmers and tourism representatives, it is one of the most singular and innovative arrangements for the exchange of waters of different qualities in the Spanish Mediterranean coast, and probably in the Mediterranean areas as well (Gil Olcina \& Rico Amorós, 2015).

In contrast, Catalonia barely uses the 3 percent of the potential reclaimed water, despite the generally higher complexity of treatment. Irrigation, at least at a certain scale, does not appear to be a realistic option for reclaimed water, basically because the large irrigated areas such as the Lleida plain, the Ebro lower valley and delta, or the irrigation perimeters of Girona are far from the large urban centers and, perhaps with the exception of Girona, have already relatively abundant surface sources. Deprived from a traditional and socially well accepted alternative for treated effluents, water reuse in Catalonia must resort to newer and more demanding uses in terms of quality such as environmental flows such as the aforementioned hydraulic barrier against seawater intrusion in the Llobregat river delta created by the injection of reclaimed water into the coastal aquifer. Hence, more stringent water quality requirements together with generally still high pollution loads, require higher energy intensities. Additionally, further uses for reclaimed water in Catalonia (generally in lower amounts) include recreational, municipal and some agricultural irrigation.

In contrast with Valencia, reclaimed water in Catalonia might find its way into drinking water plants through indirect means. By national regulation (RD 1620/2007), direct reuse for potable purposes is prohibited in Spain, but several recent initiatives are looking at indirect reuse by means of a river or aquifer, as done in California and other areas. For example, in 2018 the tourist resort of El Port de la Selva, (Costa Brava) started a project to improve municipal water supply from an aquifer partly containing reclaimed water from the municipal WWTP. The effluent is directed towards the recharge area and infiltrates into the aquifer to complete treatment. As said before, the WWTP of El Prat de Llobregat, near Barcelona, equipped with reverse osmosis technology plus nutrient removal, produces a final effluent apt for its processing in a drinking water plant. During the drought of 2008 the Catalan Water Agency (ACA) proposed a pilot test of pumping reclaimed water from this facility upstream the Llobregat River until about eight kilometers before one of the drinking water plants supplying Barcelona. It was assumed that reclaimed water mixed with river water would complete the treatment process before being diverted to the plant. Finally, this alternative was disregarded 
due to the end of the drought period. However, it was proven that indirect potable reuse could become a suitable alternative for future episodes of water stress in the Barcelona area.

\section{Conclusions}

The paper has presented a benchmarking analysis of WWTPs in terms of energy intensity for two different geographical areas: Europe (through data provided by the EU project ENERWATER) and the Spanish Mediterranean regions of Catalonia and Valencia. Benchmarking may be useful to assess wastewater treatment facilities in terms of energy intensity. However, a pervasive challenge for the Spanish Mediterranean WWTPs is the availability of reliable data regarding treatment technologies and their energy requirements.

The first benchmarking analysis in the paper involved the comparison between European WWTPs and the Mediterranean plants of Catalonia and Valencia, whereas in the second analysis the WWTPs of the two Spanish Mediterranean areas were compared with more detail. The main findings of this study are as follows: first, on average, smaller WWTPs require higher energy intensities i.e. more $\mathrm{kWh} / \mathrm{m}^{3}$ of effluent treated; second, Mediterranean WWTPs appear to be less energy intensive than European WWTPs up to a certain size, either because Mediterranean wastewaters do not carry pollution loads as high as their European counterparts, or because Mediterranean plants are smaller and the treatments simpler (for bigger installations, Mediterranean WWTPs are more energy intensive than European WWTPs). Third, the comparison between Catalan and Valencian WWTPs also yielded interesting results: Catalan WWTPs appear to follow a more centralized model with a wide range of treatments, whereas Valencian WWTPs are more decentralized with smaller WWTPs and less sophisticated treatments -although occasionally e.g. in Benidorm, these treatments may be highly complex. More advanced treatments including membranes are generally used in bigger WWTPs, whereas simpler treatments (e.g. ponds) are used in smaller WWTPs. Moreover, a more intensive combination of technologies does not always imply more energy consumption in unitary terms; on the contrary, the installation of controlled and optimised energy systems helps to reduce energy consumption of the facility. Finally, the amount and destination of water for reuse also shows the different economic and social Geography of the two Spanish Mediterranean areas: in Valencia, irrigation is the traditional destination of reclaimed water due to the proximity between urban centres and areas of irrigated agriculture; frequent episodes of water stress, and trust in the quality of effluent. In Catalonia, water reuse is mainly directed to environmental purposes, for example the freshwater hydraulic barrier in the Llobregat river delta aquifer to counterbalance seawater intrusion or the supply of reclaimed water to coastal wetland areas. There are also several examples of small scale irrigation, including the irrigation of golf courses. Regarding the demand for urban non-potable uses, municipalities show interest as long as the production and distribution costs of reclaimed water are lower than those of network water 
which is not always the case. In some cases (for instance the Consorci Besòs Tordera in Catalonia) master plans for reclaimed water are developed at the river basin scale. Thanks to the progress made in the quality of WWTP effluents, direct potable reuse is an option perfectly suitable from a technological point of view although its social acceptance would probably be much more complex. In this sense, it would be critical for autonomous communities to develop specific legislation on reclaimed water to promote the use of this resource and advance towards a more circular approach to water management.

Acknowledgments: The authors would like to thank the editor of the Journal and two anonymous referees for helpful comments on a previous version of the manuscript. Research supportive of the paper was funded by the Spanish CICYT under grant CSO2015-65182-C2-1-P, by the Industrial Doctorate Programme (ref. 2017-DI-048) of the Catalan Agency of University and Research Grants Management (AGAUR) and by DAM (Depuración de Aguas del Mediterráneo). The authors would also like to thank the water agencies, ACA (Catalonia) and EPSAR (Valencia) and other local water organisations for information and data on WWTPs and reuse projects.

Authorship statement: The authors declare no conflict of interest. Paula Rodriguez-Villanueva searched data on WWTPS and their characteristics in Catalonia and Valencia, produced part of maps and charts and contributed to the writing of the paper. David Palma compiled the data needed from the ENERWATER project; produced part of the charts and contributed to the writing of the paper. Manel Poch contributed to the writing of the paper, especially the discussion and conclusion sections. Miquel Angel Cugueró contributed to the writing of the paper, especially Section 2. Finally, David Sauri took care of the design and organization of the paper as well as of the final writing and editing. 


\section{References}

Agència Catalana de I'Aigua (ACA) (2009). Programa de Reutilització d'Aigua a Catalunya. https://acaweb.gencat.cat/aca/documents/ca/planificacio/reutilitzacio/PRAC_V_3_1.pdf

Aznar-Crespo, P., Aledo, A., \& Melgarejo, J. (2019). Percepción social e implementación de la reutilización de aguas regeneradas por parte de Comunidades de Regantes. In J. Melgarejo (Ed.), Congreso Nacional del Agua. Innovación y Sostenibilidad. Libro de Actas (pp. 759-772). Alicante: Universidad de Alicante \& HIDRAQUA.

Browning-Aiken, A., Ormerod, K.J., \& Scott, C. A. (2011). Testing the Climate for Non-Potable Water Reuse: Opportunities and Challenges in Water-Scarce Urban Growth Corridors. Journal of Environmental Policy \& Planning, 13(3), 253-275.

https://doi.org/1010.1080/1523908X.2011.594597

Cabrera Jr., E., Dane. P., Haskins, S., \& Theuretzbacher-Fritz, E. (2011). Benchmarking Water Services. London: IWA Publishing.

Choukr-Allah, R., Ragab, R., \& Rodriguez-Clemente, R. (Eds) (2012). Integrated Water Resources Management in the Mediterranean Region. Dordrecht: Springer.

Cramer, W., Guiot, J., Fader, M., Garrabou, J., Gattuso, J.-P., Iglesias, A., ... Xoplaki, E. (2018). Climate change and interconnected risks to sustainable development in the Mediterranean. Nature Climate Change, 8(11), 972-980. https://doi.org/10.1038/s41558-018-0299-2

Drewes, J. E., Horstmeyer, N., Michel, P., \& Khan, S. (2017). Producing high-quality recycled water. In J. Lema \& S. Suarez (Eds), Innovative Wastewater Treatment \& Resource Recovery Technologies (pp. 285-294). London: IWA Publishing.

Duong, K., \& Saphores, J.D. (2015). Obstacles to wastewater reuse: an overview. WIREs Water, 2, 199-214. https://doi.org/10.1002/wat2.1074

ENERWATER Consortium (2015). H2020 Project ENERWATER: Deliverable 2. 1 Study of published energy data. http://www.enerwater.eu/wp-content/uploads/2015/10/ENERWATER_D2.1-Studyof-published-energy-data-Will-contain-data-of-at-least-500-WWTPs.pdf

ENERWATER Consortium (2016). Energy Benchmarking Database-Enerwater. https://docs.google.com/spreadsheets/d/1UPHWYIR76Ef7G_JO2YwlbBIUTTIE9EQGwaz151oVI 7g/edit\#gid=1369108923

European Comission (2018). Water reuse: Commission proposes measures to make it easier and safer for agricultural irrigation. Retrieved from http://europa.eu/rapid/press-release_IP-183929 en.htm 
European Environmental Agency (2018). UWWTD Data for Spanish WWTPs along year 2018 collected by the European Environmental Agency in compliance to implementation of Urban Waste Water Treatment Directive 91/271/EEC. Retrieved from http://cdr.eionet.europa.eu/es/eu/uwwt/envxfwkgg/Q2017_UWWTDArt15_20190211.xls/man age_document

Fawell, J., Le Corre, L., \& Jeffrey, P. (2016). Common or independent? The debate over regulations and standards for water reuse in Europe. International Journal of Water Resources Development. 32(4), 559-572. https://doi.org/10.1080/07900627.2016.1138399

Hu, Z., Houweling, D., \& Dold, P. (2012). Biological Nutrient Removal in Municipal Wastewater Treatment: New Directions in Sustainability. Journal of Environmental Engineering, 138(3), 307317. https://doi.org/10.1061/(ASCE)EE. 1943-7870.0000462

Gil Olcina, A., \& Rico Amorós, A.M. (2015). Consorcio de Aguas de la Marina Baja. Gestión convenida, integral y sostenible del agua. Alicante: Universidad de Alicante, Instituto Interuniversitario de Geografía.

Iglesias, A., Garrote, L., Flores, F., \& Moneo, M. (2007). Challenges to Manage the Risk of Water Scarcity and Climate Change in the Mediterranean. Water Resources Management, 21(5), $775-$ 788. hitps://doi.org/10.1007/s11269-006-9111-6

IWA Publishing (2016). Activated Sludge Process. Retrieved from https://www. iwapublishing.com/news/activated-sludge-process

Kaika, M. (2003). The Water Framework Directive: A New Directive for a Changing Social, Political and Economic European Framework. European Planning Studies, 11(3), 299-316. hitps://doi.org/10.1080/09654310303640

Kellis, M., Kalavrouziotis, I.K., \& Gikas, P. (2013). Review of Wastewater Reuse in Mediterranean Countries, focusing on regulations and policies for municipal and industrial applications, Global NEST Journal, 15 (3), 333-350.

López Peñalver, F.J., Melián Navarro, A., Ruiz Canales, A., Piccinetti, L., Egea Pérez, R., \& Chazarra Zapata, J.P. (2019). Uso del agua regenerada en la Europa mediterránea. Beneficio hídrico, perjuicio económico. In J. Melgarejo (Ed.), Congreso Nacional del Agua. Innovación y Sostenibilidad. Libro de Actas (pp. 913-924). Alicante: Universidad de Alicante \& HIDRAQUA.

Malagò A., \& Bouraoui F. (2018) Water Quality Modeling in the Mediterranean River Basins. In A. Kallel, M. Ksibi, H. Ben Dhia \& N. Khélifi (Eds.), Recent Advances in Environmental Science from the Euro-Mediterranean and Surrounding Regions. EMCEI 2017. Advances in Science, Technology \& Innovation (IEREK Interdisciplinary Series for Sustainable Development). Springer Nature 
Muralikrishna, I.V., Manickam, V. Shah, A., \& Davergave, N. (2017). Wastewater Treatment Technologies. In Environmental Management. Science and Engineering for Industry (pp. 249293). https://doi.org/10.1016/B978-0-12-811989-1.00012-9

Olcina Cantos, J.m \& Moltó Mantero, E. (2010). Recursos de Agua no Convencionales en España. Estado de la Cuestión 2010. Investigaciones Geográficas, 51, 131-163. https://doi.org/10.14198/INGEO2010.51.06

Rico Amorós, A. M., Olcina Cantos, J., Paños Callado, V., \& Baños Castiñeira, C. (1998). Depuración, desalación y reutilización de aguas en España. Vilassar de Mar: Oikos-Tau.

Sauri, D., \& Arahuetes, A. (2019) Water reuse: A review of recent international contributions and an agenda for future research. Documents d'Anàlisi Geogràfica, 65(2), 399-417.

Scholz, M. (2006). Activated sludge processes. In Wetland Systems to Control Urban Runoff (pp. 9-105). Amsterdam: Elsevier

Solomon, B.D., \& Calvert, K.E. (Eds.) (2017). Handbook on the Geographies of Energy. Chnetelham UK, Edward Elgar Publishing.

Stijn, B., Maas, T., Smith, H., \& Frijns, J. (2015). Trust in Water Reuse: Review report on international experiences in public involvement and stakeholder collaboration (Deliverable 5.2 Demoware Project). Retrieved from http://demoware.eu/en/results/deliverables

Sustainable Sanitation and Water Management Toolbox (2018). Waste Stabilisation Ponds. Retrieved from https://sswm.info/node/8199

New South Wales Government (2010). Stage 3-Tertiary treatment. Wastewater treatment plant virtual tour. Retrieved from

https://www.sydneywater.com.au/Education/Tours/virtualtour/html/tertiary-treatment.html

United States Environmental Protection Agency (USEPA) (2011). Principles of Design and Operations of Wastewater Treatment Pond Systems for Plant Operators, Engineers, and Managers. Retrieved from https://www.epa.gov/sites/production/files/201409/documents/lagoon-pond-treatment-2011.pdf

Water Online (2013). Biological Nutrient Removal. Retrieved from https://www.wateronline.com/doc/biological-nutrient-0001

Wester, J., Timpano, K., Çek, D., \& Broad, K. (2016). The psychology of recycled water: Factors predicting disgust and willingness to use. Water Resources Research, 52, 3212-3226, https://doi:10.1002/2015WR018340

WWAP (United Nations World Water Assessment Programme) (2017). Wastewater: The Untapped Resource (The United Nations World Water Development Report 2017). Paris: UNESCO. Retrieved 
from hitp://www.unesco.org/new/en/natural-sciences/environment/water/wwap/wwdr/2017wastewater-the-untapped-resource/

Yoon, H. (2019). A Review on Water-Energy Nexus and Directions for Future Studies: From Supply to Demand End. Documents d'Anàlisi Geogràfica, 64(2), 365-395.

https://doi.org/10.5565/rev/dag.438 